\title{
Identifikasi Metabolit Sekunder \& Aktivitas Antioksidan Ekstrak Patah Tulang (Euphorbia tirucalli)
}

\author{
Muhammad Nasir ${ }^{1 *}$, Lizma Febrina ${ }^{1}$, Muhammad Amir $\mathbf{M}^{\mathbf{2}}$. \\ Laboratorium Penelitian dan Pengembangan Kefarmasian FARMAKA TROPIS \\ Fakultas Farmasi Universitas Mulawarman, Samarinda \\ ${ }^{2}$ Fakultas Keguruan dan Ilmu Pengetahuan Universitas Mulawarman, Samarinda \\ *email : mnasir216@gmail.com
}

\begin{abstract}
ABSTRAK
Telah dilakukan penelitian mengenai identifikasi metabolit sekunder \& aktivitas antioksidan ekstrak patah tulang (Euphorbia tirucalli). Identifikasi metabolit sekunder dilakukan secara kualitatif berdasarkan reaksi antara ekstrak dengan pereaksi metabolit sekunder yang akan diidentifikasi. Uji aktivitas antioksidan menggunakan metode peredaman radikal bebas DPPH (1,1-diphenyl-2-picrylhyrazil). Berdasarkan hasil pengujian metabolit sekunder, diketahui ekstrak patah tulang mengandung fenol, flavanoid, tanin dan steroid. Hasil pengujian aktivitas antioksidan, diketahui ekstrak patah tulang memiliki potensi sebagai antioksidan yang ditunjukkan dengan nilai $\mathrm{IC}_{50}$ yaitu sebesar 52,67 ppm. Potensi antioksidan ekstrak patah tulang ini selanjutnya akan digunakan sebagai peredam radikal bebas yang ditimbulkan dari asap rokok.
\end{abstract}

Kata Kunci : Metabolit Sekunder, Aktivitas Antioksidan, Ekstrak Patah Tulang (Euphorbia tirucalli)

\section{ABSTRACT}

Has done research on secondary metabolite identification and antioxidant activity of patah tulang (Euphorbia tirucalli) extracts. Identification of secondary metabolites performed qualitatively based on reaction between extracts with reactant secondary metabolites that are identified. Testing of antioxidant activity using the DPPH (1,1-diphenyl-2-picrylhyrazil) free radical attenuation method. Based on the testing results of secondary metabolites, known to patah tulang exctract contains phenol, flavanoid, tannin and steroid. The results are known, the antioxidant activity patah tulang extract has potential as an antioxidant shown with IC50 values i.e. of 52,67 ppm. The antioxidant potential of these patah tulang extracts will then be used as free-radical reducer caused from cigarette smoke.

Keywords : Secondary metabolite, Antioxidant Activity, Patah Tulang (Euphorbia tirucalli) Extract

\section{PENDAHULUAN}

Radikal bebas adalah molekul atau bagian molekul yang tidak utuh lagi karena sebagian telah pecah atau melepaskan diri. Bagian yang pecah atau melepaskan diri ini melekat pada molekul lain dan merusak atau mengubah struktur atau fungsi molekul yang bersangkutan (Tambayong, 2000). Ada dua sumber radikal bebas, yaitu endogen dan eksogen. Radikal bebas eksogen berasal dari lingkungan yang tercemar oleh asap kendaraan, 
limbah pabrik/industri, senyawa kimia beracun, asap rokok, radiasi sinar matahari, ozon dan sinar ultraviolet.

Dalam keadaan normal, radikal bebas endogen dapat dikendalikan oleh mekanisme alamiah tubuh. Namun, dengan adanya radikal bebas eksogen yang semakin sulit dihindari dan kualitasnya meningkat terus setiap waktu, tubuh mengalami stres oksidatif atau kelebihan radikal bebas. Hal ini mengakibatkan ketidakseimbangan dan gangguan mekanisme pengendalian efek merusak dari radikal bebas sehingga terjadi kerusakan secara beruntun pada sel-sel organ tubuh (Yuliarti, 2010).

Senyawa antioksidan adalah senyawa pemberi elektron (electron donors). Secara biologis, pengertian antioksidan adalah senyawa yang mampu menangkal atau meredam dampak negatif oksidan dalam tubuh. Antioksidan bekerja dengan cara mendonorkan satu elektronnya kepada senyawa yang bersifat oksidan sehingga aktivitas senyawa oksidan tersebut dihambat (Winarsi, 2007).

Hasil uji fitokimia pada ekstrak patah tulang (Euphorbia tirucalli L.) menunjukkan adanya kandungan alkaloid yang terlarut pada kloroform dan kandungan flavanoid, tanin, dan saponin yang terlarut pada metanol (Oratmangun dkk., 2014). Flavanoid memiliki kemampuan untuk merubah atau mereduksi radikal bebas juga sebagai anti radikal bebas. Sehingga penelitian ini untuk mengungkap daya antioksidan ekstrak patah tulang (Euphorbia tirucalli L.)

\section{METODE PENELITIAN}

\section{Bahan}

Bahan yang digunakan dalam penelitian ini adalah patah tulang (Euphorbia tirucalli L.) yang diperoleh dari Kecamatan Linggang Bigung, Kabupaten Kutai Barat, Kalimantan Timur, DPPH (1,1-diphenyl-2-picrylhyrazil), metanol, kloroform, $\mathrm{H}_{2} \mathrm{SO}_{4}$ pekat, $\mathrm{FeCl}_{3}, \mathrm{HCl}$ $2 \%$, asam asetat anhidrat, reagen dragendorf, reagen meyer, serbuk $\mathrm{Mg}$ dan $\mathrm{HCl}$ pekat.

\section{Peralatan}

Alat yang digunakan dalam penelitian ini adalah almari pengering, vacuum rotary evaporator, neraca analitik, spektrofotometer Uv-Vis, mikropipet 100-1000 $\mu \mathrm{L}$, blue tip, dan alat-alat gelas yang lazim digunakan di laboratorium analisis.

\section{Prosedur Penelitian}

\section{Pembuatan Simplisia}

Sampel patah tulang yang telah dikumpulkan disortir kemudian dibersihkan dan ditimbang sebanyak 4,3 kg, kemudian dirajang kecil-kecil dan dikeringkan menggunakan oven hingga diperoleh simplisia patah tulang kering. Kemudian ditimbang berat keringnya yaitu diperoleh 840,7 gram dan dilakukan penghalusan menjadi serbuk simplisia.

\section{Pembuatan Ekstrak}

Potongan kecil simplisia sebanyak 840,7 gram diekstraksi dengan menggunakan metode maserasi yaitu dengan cara merendam seluruh bagian serbuk kering dengan pelarut metanol. Dari hasil ekstraksi tersebut diperoleh residu dan larutan ekstrak patah tulang, kemudian disaring ampasnya dan disisihkan, bagian ekstrak cair hasil maserasi diuapkan dengan menggunakan rotary evaporatior pada suhu $30-45{ }^{\circ} \mathrm{C}$ hingga diperoleh ekstrak kental. Sisa pelarut selanjutnya diuapkan di atas water bath untuk memperoleh ekstrak kering. 


\title{
Penentuan Rendemen
}

Ditimbang patah tulang segar, patah tulang yang telah dikeringkan (simplisia) dan ekstrak metanol hasil maserasi. Selanjutnya dicatat dan dihitung jumlah rendemen sesuai dengan rumus perhitungan rendemen ekstrak yaitu berat ekstrak (g) dibagi dengan berat sampel kering sebelum ekstraksi (g) dikali $100 \%$, sehingga diperoleh nilai persen (\%) rendemen.

\section{Identifikasi Metabolit Sekunder}

\begin{abstract}
Alkaloid
Sebanyak $2 \mathrm{~mL}$ ekstrak diuapkan di atas cawan porselin. Residu yang dihasilkan kemudian dilarutkan dengan $5 \mathrm{~mL} \mathrm{HCl} 2 \mathrm{M}$. Larutan yang diperoleh dibagi ke dalam 3 tabung reaksi. Tabung pertama berfungsi sebagai blanko, ditambahkan dengan 3 tetes $\mathrm{HCl}$ 2 M. Tabung kedua ditambahkan 3 tetes pereaksi Dragendorff dan tabung ketiga ditambahkan 3 tetes pereaksi Mayer. Pada pereaksi Dragendorff akan terbentuk endapan berwarna jingga sedangkan pereaksi Mayer akan terbentuk endapan kuning yang menandakan positif adanya alkaloid.
\end{abstract}

\section{Fenol}

Ekstrak sampel sebanyak $1 \mathrm{ml}$ dimasukkan ke dalam tabung reaksi untuk dilakukan pengujian fenolik dengan cara ekstrak ditambahkan pereaksi $\mathrm{FeCl} 3$ 1\%, jika terjadi warna hitam menunjukkan adanya senyawa fenolik.

\section{Flavanoid}

Sebanyak $2 \mathrm{~mL}$ ekstrak ditambahkan dengan air panas secukupnya, kemudian dididihkan selama 5 menit lalu disaring. Filtrat sebanyak $5 \mathrm{~mL}$ ditambahkan 0,05 mg serbuk $\mathrm{Mg}$ dan $1 \mathrm{~mL} \mathrm{HCl}$ pekat, kemudian dikocok kuat-kuat. Uji positif ditunjukkan dengan terbentuknya warna merah, kuning atau jingga.

\section{Tanin}

Sebanyak $1 \mathrm{~mL}$ ekstrak ditambahkan dengan beberapa tetes larutan besi (III) klorida $10 \%$. Jika terjadi warna biru tua atau hitam kehijauan menunjukkan adanya tanin.

\section{Steroid}

Sebanyak $2 \mathrm{~mL}$ ekstrak ditambahkan $\mathrm{CH}_{3} \mathrm{COOH}$ anhidrat sebanyak 10 tetes dan $\mathrm{H}_{2} \mathrm{SO}_{4}$ pekat sebanyak 2 tetes. Larutan dikocok perlahan dan dibiarkan selama beberapa menit. Adanya steroid ditunjukan oleh warna biru atau hijau, sedangkan triterpenoid memberikan warna merah atau ungu.

\section{Saponin}

Sebanyak 2-3 mL ekstrak dimasukkan ke dalam tabung reaksi, kemudian ditambahkan $10 \mathrm{~mL}$ air panas lalu dikocok kuat-kuat selama 10 detik, kemudian didinginkan lalu ditambahkan 1 tetes $\mathrm{HCl} 2 \mathrm{~N}$. Uji positif ditunjukkan dengan terbentuknya buih yang stabil setinggi $1-10 \mathrm{~cm}$ selama tidak kurang dari 10 menit.

\section{Penentuan Aktivitas Antioksidan secara Kuantitatif dengan metode DPPH}

Larutan DPPH 40 ppm dibuat dengan melarutkan $4 \mathrm{mg}$ serbuk DPPH dalam metanol pada labu takar $100 \mathrm{~mL}$, kemudian divorteks. Ekstrak metanol patah tulang dilarutkan dalam metanol dalam konsentrasi $0,1 \% \mathrm{~b} / \mathrm{v}$ dan dilakukan seri pengenceran hingga diperoleh konsentrasi 5 ppm, 10 ppm, 20 ppm, 30 ppm dan 40 ppm. Sebanyak $2 \mathrm{~mL}$ sampel uji tiap- 
tiap seri konsentrasi dimasukkan ke dalam tabung reaksi bertutup dan ditambahkan $2 \mathrm{~mL}$ DPPH 40 ppm, divorteks selama 1 menit hingga campuran homogen dan didiamkan selama 30 menit. Larutan ini kemudian diukur absorbansinya pada panjang gelombang 515,9 nm yang didapatkan dari uji pendahuluan. Dilakukan pula pembacaan absorbansi kontrol negatif yaitu tanpa penambahan larutan uji. Besarnya aktivitas antioksidan dihitung dengan rumus : $(\%)=\frac{(\text { Abs.kontrol-Abs.sampel })}{\text { Abs kontrol }} \times 100 \%$

Data absorbansi yang diperoleh dibuat persamaan regresi linier yang menyatakan hubungan antara konsentrasi bahan uji (x) dengan aktivitas antioksidan rata-rata (y) dari suatu seri replikasi pengukuran sehingga diperoleh harga $\mathrm{IC}_{50}$ yaitu konsentrasi bahan uji yang diperlukan untuk menangkap 50\% radikal DPPH selama 30 menit (operating time) atau jeda waktu yang dibutuhkan oleh bahan uji untuk mereduksi radikal DPPH dengan sempurna.

\section{HASIL DAN PEMBAHASAN}

Ekstrak metanol patah tulang yang diperoleh dari proses ekstraksi dengan metode maserasi menghasilkan rendemen ekstrak sebanyak 6,4\%. Hasil uji kualitatif dari identifikasi metabolit sekunder ekstrak patah tulang sebagai berikut :

Tabel 1. Identifikasi Golongan Metabolit Sekunder

\begin{tabular}{ccc}
\hline No & Uji & Hasil \\
\hline 1 & Alkaloid & - \\
2 & Fenol & + \\
3 & Flavanoid & + \\
4 & Tanin & + \\
5 & Steroid & + \\
6 & Saponin & - \\
\hline
\end{tabular}

Berdasarkan identifikasi metabolit sekunder ekstrak patah tulang yang terdapat pada Tabel 1 menunjukkan bahwa sampel mengandung senyawa fenol, flavanoid, tanin dan steroid. Hal ini menunjukkan bahwa sampel memiliki potensi sebagai antioksidan dengan adanya senyawa flavanoid dan fenol. Hasil positif mengandung senyawa flavanoid ditunjukkan dengan adanya perubahan warna larutan menjadi kuning. Identifikasi senyawa fenol dengan penambahan pereaksi $\mathrm{FeCl}_{3}$ pada sampel uji menimbulkan perubahan warna menjadi larutan hitam yang menandakan sampel uji positif mengandung senyawa fenol.

Uji aktivitas antioksidan ekstrak patah tulang dengan menggunakan metode DPPH untuk mengukur kemampuan suatu senyawa antioksidan dalam menangkap radikal bebas. Kemampuan penangkapan radikal berhubungan dengan kemampuan komponen senyawa dalam menyumbangkan elektron atau hidrogen. Setiap molekul yang dapat menyumbangkan elektron atau hidrogen akan bereaks dan akan memudarkan DPPH. Intensitas warna DPPH akan berubah dari ungu menjadi kuning oleh elektron yang berasal dari senyawa antioksidan. Konsentrasi DPPH pada akhir reaksi tergantung pada konsentrasi awal dan struktur komponen senyawa penangkap radikal. 
Tabel 2.\% Aktivitas Peredaman Radikal DPPH

\begin{tabular}{|c|c|c|c|c|c|c|c|}
\hline \multirow{3}{*}{$\begin{array}{c}\text { Konsentrasi } \\
\text { Sampel } \\
\text { (ppm) }\end{array}$} & \multirow{2}{*}{\multicolumn{3}{|c|}{$\begin{array}{c}\text { Absorbansi Sampel } \\
\text { Setiap Ulangan }\end{array}$}} & \multirow{3}{*}{$\begin{array}{l}\text { Rata- } \\
\text { Rata }\end{array}$} & \multirow{3}{*}{$\begin{array}{c}\% \\
\text { Aktivitas }\end{array}$} & \multirow{3}{*}{$\begin{array}{l}\text { Nilai } \\
\mathrm{IC}_{50} \\
(\mathrm{ppm})\end{array}$} & \multirow{3}{*}{$\begin{array}{c}\text { Kategori } \\
\text { Daya } \\
\text { Antioksidan }\end{array}$} \\
\hline & & & & & & & \\
\hline & I & II & III & & & & \\
\hline 5 & 0,406 & 0,406 & 0,412 & 0,408 & $8,52 \%$ & & \\
\hline 10 & 0,381 & 0,435 & 0,391 & 0,402 & $9,86 \%$ & & \\
\hline 20 & 0,360 & 0,431 & 0,367 & 0,386 & $13,45 \%$ & 52,67 & Sedang \\
\hline 30 & 0,310 & 0,333 & 0,346 & 0,330 & $26 \%$ & & \\
\hline 40 & 0,252 & 0,257 & 0,267 & 0,258 & $42,15 \%$ & & \\
\hline
\end{tabular}

Menurut Herman (2013), secara spesifik suatu senyawa dikatakan sebagai antioksidan jika nilai $\mathrm{IC}_{50}$ kurang dari 200 ppm nilai $\mathrm{IC}_{50}$ dan jika yang diperoleh berkisar antara 200 sampai 1000 ppm, maka zat tersebut kurang aktif namun masih berpotensi sebagai zat antioksidan Semakin rendah nilai $\mathrm{IC}_{50}$ mengindikasikan aktivitas yang tinggi. $\mathrm{IC}_{50}$ kurang dari 50 ppm sangat aktif atau kuat, sedangkan jika nilai $\mathrm{IC}_{50}$ berkisar $50 \mathrm{ppm}$ sampai 100 ppm cukup aktif atau sedang, 100 ppm sampai 200 ppm sedikit aktif atau lemah. Jika nilai IC 50 lebih dari 200 ppm tidak aktif. Berdasarkan Tabel 2 di atas dapat diketahui bahwa sampel diujikan memiliki aktivitas antioksidan yang sangat baik, hal ini dapat dilihat dari besaran nilai $\mathrm{IC}_{50}$ dari ekstrak patah tulang diperoleh kurang dari 200 ppm.

Berdasarkan hasil tersebut diatas terlihat bahwa ada hubungan antara golongan senyawa metabolit sekunder dengan aktivitas antioksidan dari sampel yang diujikan. Senyawa flavanoid dan fenolik telah diketahui memiliki berbagai efek biologis seperti aktivitas antioksidan melalui mekanisme sebagai pereduksi, penangkap radikal bebas, pengkhelat logam, peredam terbentuknya oksigen singlet serta pendonor elektron. Senyawa fenolik yaitu senyawa dengan suatu gugus hidroksi $(-\mathrm{OH})$ yang terikat pada karbon cincin aromatik.

\section{KESIMPULAN}

Patah tulang memiliki kandungan senyawa-senyawa antioksidan seperti flavanoid dan fenol yang dapat dimanfaatkan secara luas dibidang kesehatan. Dengan nilai $\mathrm{IC}_{50}$ yang cukup kecil yaitu 52,67 ppm, ekstrak patah tulang berpotensi untuk dimanfaatkan secara luas sebagai bahan kefarmasian.

\section{SARAN}

Diperlukan penelitian lanjutan untuk mengetahui potensi antioksidan ekstrak patah tulang sebagai peredam radikal bebas yang ditimbulkan oleh asap rokok.

\section{DAFTAR PUSTAKA}

Herman, 2013, Aktivitas Antioksidan Beberapa Tumbuhan Obat Kalimantan Timur. Journal of Tropical Pharmacy and Chemistry. Vol.2 No.2 hal.4-5.

Oratmangun, S.A., Fatimawali dan Bodhi, W., 2014, Uji Toksisitas Ekstrak Tanaman Patah Tulang (Euphorbia tirucalli L.) Terhadap Artemia salina dengan Metode Brine Shrimp Lethality Test (BSLT) sebagai Studi Pendahuluan Potensi Anti Kanker. Pharmacon Jurnal Ilmiah Farmasi-UNSRAT. Vol.3 No.3 hal.2.

Tambayong, J., 2000, Patofisisologi untuk Keperawatan. EGC. Jakarta.

Winarsi, H., 2007, Antioksidan Alami dan Radikal Bebas. Kanisius. Yogyakarta.

Yuliarti, N., 2010, Sehat, Cantik, Bugar Dengan Herbal Dan Obat Tradisional. Andi. Yogyakarta. 